\title{
Effect of different levels and sources of calcium on post harvest physiology of hybrid tomatoes (Solanum lycopersicum)
}

\section{S. Salma Santhosh}

Department of Soil Science and Agricultural Chemistry, Tamil Nadu Agricultural University, Coimbatore (Tamil Nadu), India

\section{T. Chitdeshwari*}

Department of Soil Science and Agricultural Chemistry,Tamil Nadu Agricultural University, Coimbatore (Tamil Nadu), India

\section{Jegadeeswari}

Department of Soil Science and Agricultural Chemistry, Tamil Nadu Agricultural University, Coimbatore (Tamil Nadu), India

\section{Kavitha}

Department of Fruit Science, HC\&RI, Tamil Nadu Agricultural University, Coimbatore (Tamil Nadu), India

${ }^{*}$ Corresponding author. Email:chithukesh@gmail.com

\section{Article Info}

https://doi.org/10.31018/

jans.v13i4.3058

Received: September 26, 2021

Revised: November 8, 2021

Accepted: November 13, 2021

\section{How to Cite}

Santhosh, S. S. et al. (2021). Effect of different levels and sources of calcium on post harvest physiology of hybrid tomatoes (Solanum lycopersicum). Journal of Applied and Natural Science, 13(4), 1357 - 1364. https://doi.org/10.31018/jans.v13i4.3058

\begin{abstract}
Due to high respiration and ethylene production, tomato (Solanum lycopersicum) is highly perishable horticulture produce that deteriorates faster during the post-harvest storage period. Calcium nutrition is important to overcome these losses as it helps in retarding ripening process during storage and improve the post-harvest quality tomatoes. Hence a field experiment was conducted with different calcium sources and levels viz., Calcium sulphate, Calcium Nitrate, Calcium silicate, Poultry manure and Pressmud applied at $0,20,40,60$ and $80 \mathrm{~kg} \mathrm{Ca} \mathrm{ha}^{-1}$. A storage study was conducted in a factorial completely randomized block design (FCRD) to ensure the effective role of calcium in post-harvest quality of hybrid tomato. Tomatoes were analyzed for $\mathrm{pH}$ of fruit juice, firmness, titratable acidity, total soluble solids, moisture content and physiological loss at five days intervals upto 15 days. The results revealed thatCalcium sources and levels had highly significant impacts on the quality of tomato fruits. The tomatoes harvested from the plot applied with poultry manure at $80 \mathrm{~kg} \mathrm{Ca} \mathrm{ha}^{-1}$ retained the highest fruit firmness $\left(3.76 \mathrm{~N} \mathrm{~m}^{-1}\right)$, moisture content $(88.2 \%)$ and the lowest weight loss $(8.82 \%)$ in fruit, highertitratable acidity $(0.41 \%)$, lesser pH (3.61)andtotal soluble solids (4.23 $\left.{ }^{\circ} \mathrm{Brix}\right)$. Hence the application of poultry manure at $80 \mathrm{~kg}$ Ca ha ${ }^{-1}$ was beneficial in improving the quality and extending the storage life of hybrid tomatoes.
\end{abstract}

Keywords: Calcium nutrition, Fruit quality, Hybrid tomato, Post-harvest Physiology, Storage life

\section{INTRODUCTION}

Tomato (Solanum lycopersicum), a widely grown vegetable crop, originated in tropical America, is day-neutral, annual, herbaceous, short-lived, self-pollinated crop with diploid chromosome number and consumed in a variety of forms. It contains protein, carbohydrates, fibres, calories, vitamins and minerals (Chew et al., 2014; Sajid et al.,2020). It has been reported that tomato plays a major role in the healthy diet of human and prevents diseases such as cancer, cardiovascular and neurodegenerative diseases (Dorais et al., 2008). Though tomato has numerous benefits, as it isa highly perishable vegetable, it undergoes post-harvest losses due to the influence of storage temperature, moisture content of the fruit, ethylene production and high respiration during the ripening process of fruit (Fouda, 2017). In tomatoes, plant senescence and fruit ripening are regulated by calcium and it significantly affects the quality of fruits (Soundharya et al., 2019). This process could be controlled and delayed by calcium (Ca) fertilization, which also helps in maintaining the firmness of tomato fruits.

Calcium, a secondary nutrient increases the storage life of tomatoes by retarding ethylene production and respiration rate of fruit on ripening (Yang et al., 2012). It is considered as an important multifunctional signalling ion, which rigidifies the cell walls of the fruits by cross- 
linking the pectins, which remain fruits ambiguous. It also effectively reduces physiological diseases and maintains fruit firmness thus regulating fruit quality (Aghdam et al., 2012; Zhao and Wang, 2015; Gao et al.,2019). It has been reported that calcium could maintain the hardness of fruit by delaying the ripening and senescence process, enhancing the cold storage resistance of fruits by regulating reactive oxygen species content, inhibiting post-harvest disease and maintaining fruit quality (Madani et al., 2014; Al-Qurashi and Awad, 2019; Gao et al., 2019; Wei and Zhao, 2020).The deficiency of calcium in fruits is mainly due to limited calcium mobility throughout plants, resulting in short supply of fruits than shoots (Lobos et al., 2021). Hence, calcium application has gained more attention as it effectively delays the ripening of fruits and vegetables and also senescence to maintaining their quality (Guo et al., 2020).

Therefore, considering the major role of calcium in improving post- harvest quality and shelf-life of tomatoes by delaying the ripening and senescence of fruits, this study was conducted to know the effect of calcium fertilisation on hybrid tomatoes in maintaining the fruit quality and improving the storage life of tomatoes.

\section{MATERIALS AND METHODS}

\section{Description of the experiment}

A field experiment was conducted on a Palaviduthi soil series of the farmer's holdings at Devarayapuram, Coimbatore $\left(\mathrm{N} 11^{\circ} 00.218\right.$, E $\left.076^{\circ} 48.094\right)$ using hybrid tomato 'Shivam'. Different sources and levels of calcium fertiliser/manure inputs were applied to know the role of $\mathrm{Ca}$ in improving the growth, yield and fruit quality of hybrid tomato besides the storage life of harvested fruits.

\section{Treatments and experimental design}

The treatment comprised of two factors: factor-A (Sources) and factor-B (Levels). Factor-A consisted of six sources of calcium viz., Calcium sulphate (S1), Calcium Nitrate(S2), Calcium silicate(S3), Poultry manure (S4) and Pressmud(S5), whereas calcium levels as factor-B included $0,20,40,60,80 \mathrm{~kg} \mathrm{Caha}^{-1}$. The treatments were laid out in $5 \times 5$ factorial arrangements in a randomized block design (RBD) with three replications. The tomatoes were harvested from each treatment separately and were analyzed for post-harvest quality parameters.

\section{Cultivation Practices}

'Shivam' is considered as a ruling tomato variety by M/ s.HYVEG- Rasi Seed, Tamil Nadu, having semideterminate growth habits with good foliage cover, vigour and flat round fruits, was chosen as the test crop. The ridges and furrows were made in the experimental field after ploughing and levelling. About 25 days old seedlings of tomato hybrid were transplanted with the spacing of $45 \mathrm{~cm} \times 30 \mathrm{~cm}$. The major nutrients such as nitrogen as urea, phosphorus as di-ammonium phosphate (DAP) and potassium as muriate of potash (MOP) were applied as per Soil Test Crop Response (STCR) - Integrated Plant Nutrition System (IPNS) fertilizer prescription to achieve the targeted fruit yield of 70 tonnes ha ${ }^{-1}$. All the agronomic practices such as weeding, cultivation, irrigation were carried out as per recommendations (TNAU -Crop Production Guide, 2020).

\section{Fruit sample collection, processing and analysis}

Tomatoes were harvested at the red ripened stage from each plot separately and from which eight fruits were selected randomly from every treated plot. The collected samples were divided into two categories as destructive and non-destructive samples; each consisted of four fruits and was placed on tables separately apart from each other. Data on various fruit quality parameters was collected at five days intervals on initial, $5^{\text {th }}, 10^{\text {th }}$ and $15^{\text {th }}$ days after storage. Quality attributes of tomato fruits such as physiological weight loss (\%), moisture content $(\%)$, firmness $\left(\mathrm{N} \mathrm{m}^{-1}\right), \mathrm{pH}$, titratable acidity (\%) and total soluble solids ( ${ }^{\circ}$ Brix) of fruits werealso determined using the standard procedures given below:

\section{Physiological loss in weight (PLW)}

Moneruzzaman et al. (2008) described determining physiological loss in weight of tomato fruits where the samples from non-destructive category were weighed using the digital balance on $0^{\text {th }}, 5^{\text {th }}, 10^{\text {th }}$ and $15^{\text {th }}$ day after storage. The weight loss was calculated for each interval and converted into percentage as

$$
P L W(\%)=\frac{\text { InitialWeig } \square t(g)-\text { FinalWeig } \square t(g)}{\text { Initialweig } \square t(g)} \times 100
$$

Moisture content, firmness, pH, titratable acidity and total soluble solids

The moisture content (wet basis) in the fruits was determined using ahot air oven at $105^{\circ} \mathrm{C}$ for 6 hours until attaining constant moisture, according to the AOAC procedure (AOAC 2000). The firmness of tomato was determined by using a 'Digital Fruit Penetrometer' (Model GY-4).pH of tomato fruit juice sample was determined using electronic $\mathrm{pH}$ meter where one gram of fruit sample was homogenized in $1 \mathrm{ml}$ of boiled distilled water and $1 \mathrm{ml}$ of de-ionized. Titratable acidity of tomato juice was determined by titration against $0.1 \mathrm{~N}$ of sodium hydroxide $(\mathrm{NaOH})$ solution using phenolphthalein as an indicator and expressed in percent citric acid as proposed by Gaikwad, et al. (2020). The 
total soluble solids content in the fruit was determined using the evaporation method described by Ranganna (2000). The known weight of fruit samples was taken in a pre-weighed beaker, crushed and evaporated to dryness, keeping it in a water bath. The final weight was noted and calculated for expressing the total soluble solid content in the fruits.

\section{Statistical analysis}

The data obtained from the investigations were subjected to the analysis of variance using IBM Statistical Package for the Social Science Softwareversion 22 to determine the significance. Wherever the treatment differences were found significant, critical differences (CD) were worked out at a $5 \%$ level of significance and denoted by symbol *for $5 \%$ and ** for $1 \%$. Nonsignificant comparisons were indicated as NS.

\section{RESULTS AND DISCUSSION}

\section{Physiological loss in weight (PLW)}

The statistical analysis of data on the physiological loss in weight of tomato fruits has no significant $(P=0.05)$ differences among various calcium sources; however, significantly differ among different levels of calcium and on storage time. The average percentage loss infruit weight was 7.00 to $11.2 \%$ (Table 1). The lowest loss in weight $(4.41 \%)$ was observed in the fruit collected fromthe plots applied with poultry manure at $80 \mathrm{~kg} \mathrm{Ca}$ $\mathrm{ha}^{-1}$.The physiological weight loss was found to decrease with increased calcium concentration and increased with storage period which ranges from 5.25 to $8.52 \%$ (Fig. 1). The mean lowest loss in fruit weight throughout storage period was registered with poultry manure $(5.25 \%)$. The decreased physiological weight loss with increasing calcium levels might be due to its role as an intermolecular binding agent in stabilizing the protein-pectin complex of the middle lamella. Thus holds the cell wall structure by forming calcium pectate through interacting with pectic acid in the cell wall (Zhao and Wang, 2015; Gao et al., 2019). High calcium leads to reduced transpiration and respiration rates, and decreased loss of protein and phospholipids, decreasing the physiological weight loss of hybrid tomato and increasing the post-harvest shelf life (Wei and Zhao, 2020; Gao et al., 2019).

\section{Moisture content}

The significant impact of $\mathrm{Ca}$ fertilization on the moisture content of tomato fruits on ripening was noticed and the mean moisture content ranges from 86.3 to $90.7 \%$ (Fig. 2) among different sources. Initially, the highest moisture content $(93.7 \%)$ was found in the tomato fruits harvested from poultry manure applied at $80 \mathrm{~kg} \mathrm{Ca} \mathrm{ha}{ }^{-1}$ and the mean lowest moisture content $(85.9 \%)$ was registered in the tomatoes where no calcium was applied (NPK control). On increasing storage time, the moisture content got decreased with increasing calcium concentration (Table 2). In general, the moisture content in tomato fruits decreases on ripening which might be due to ethylene production during the onset of ripening as ethylene mediates the exchange of moisture between the ambient atmosphere and tissue water content (Frenkel and Hartman, 2012, Sotiropoulos et al., 2021).Calcium, as it retards ethylene production, reduces respiration rates, resulting in less loss of moisture content in tomato fruits (Haleema et al. 2020).

\section{Fruit firmness}

The firmness of hybrid tomato was found to be significantly influenced by various calcium sources and levels on storage period. It was evaluated for 15 days at a five-day time interval ranging from $\mathrm{N} \mathrm{m}^{-1}$ (Fig. 3). The firmness of tomato increases with increasing calcium concentration 2.54 to $5.32 \mathrm{~N} \mathrm{~m}^{-1}$ and decreases with storage time irrespective of various treatments (Fig. 4).

Table 1. Physiological loss in weight (\%) of hybrid tomatoes as influenced by various sources and levels of calcium

\begin{tabular}{|c|c|c|c|c|c|c|}
\hline \multirow{3}{*}{ Calcium sources } & \multicolumn{6}{|c|}{ Physiological weight loss (\%) } \\
\hline & \multicolumn{6}{|c|}{ Levels of calcium $\left(\mathrm{kg} \mathrm{ha}^{-1}\right)$} \\
\hline & 0 & 20 & 40 & 60 & 80 & Mean \\
\hline Calcium sulphate & $12.8 \mathrm{de}$ & $12.5 \mathrm{~d}$ & $11.2 \mathrm{~cd}$ & $10.1 \mathrm{bd}$ & 9.04ad & 11.2 \\
\hline Calcium nitrate & $12.6 \mathrm{ce}$ & $11.3 \mathrm{~cd}$ & $10.0 c$ & $8.94 b c$ & $7.84 \mathrm{ac}$ & 10.2 \\
\hline Calcium silicate & $13.8 \mathrm{ce}$ & $10.2 \mathrm{~cd}$ & $8.94 \mathrm{c}$ & $7.84 \mathrm{bc}$ & $6.74 \mathrm{ac}$ & 9.52 \\
\hline Poultry manure & $10.5 \mathrm{be}$ & $7.91 \mathrm{ad}$ & $6.61 \mathrm{ac}$ & $5.51 \mathrm{ab}$ & $4.41 \mathrm{a}$ & 7.00 \\
\hline Pressmud & 14.6be & $9.14 b d$ & $7.84 \mathrm{bc}$ & $6.74 b$ & $5.64 a b$ & 8.80 \\
\hline \multirow[t]{2}{*}{ Mean } & 12.9 & 10.2 & 8.94 & 7.84 & 6.74 & 9.33 \\
\hline & $S$ & & $\mathrm{~L}$ & & SL & \\
\hline SEd & 0.68 & & 0.60 & & 1.50 & \\
\hline$C D(P=0.05)$ & NS & & 1.20 & & 3.00 & \\
\hline
\end{tabular}

Mean of three replicates; SEd- Standard error of difference; CD-Critical difference 


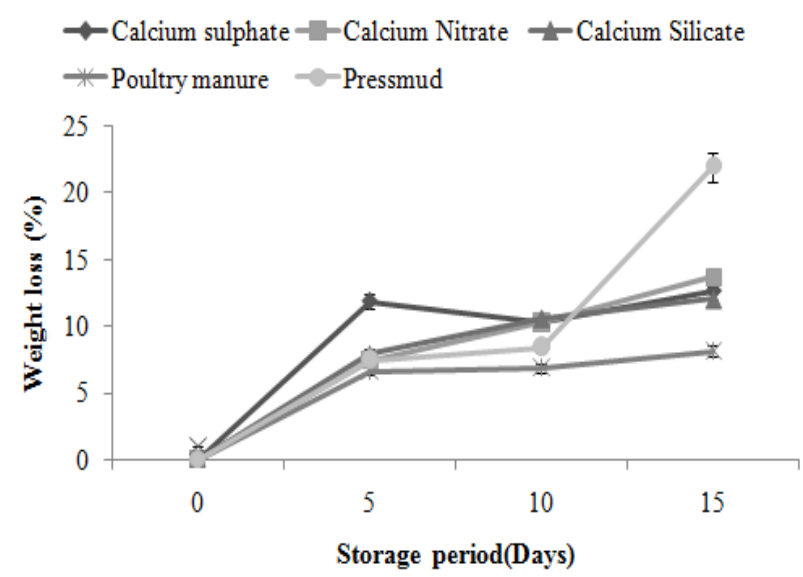

Fig. 1. Physiological loss weight (PLW) in hybrid tomatoes influenced by various sources and levels of calcium during the storage period of 15 days

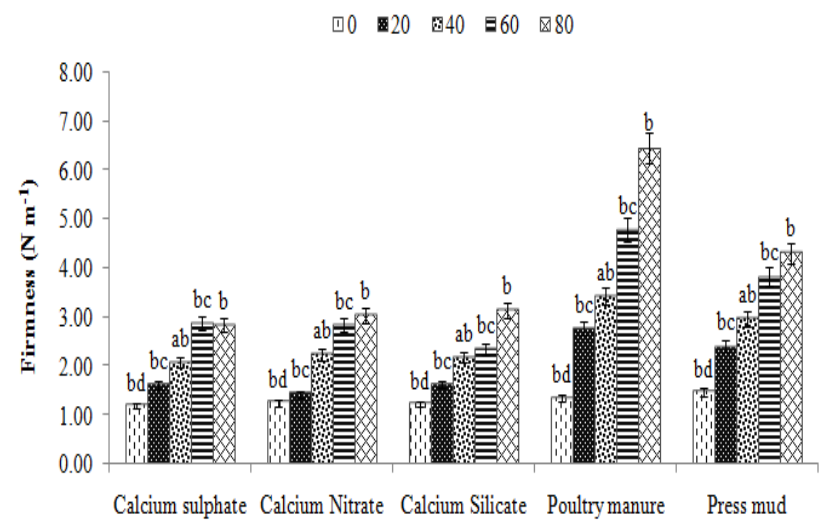

Calcium Sources $\left(\mathrm{kg} \mathrm{ha}^{-1}\right)$

Fig. 3. Changes in fruit firmness of hybrid tomato as influenced by various sources and levels of calcium

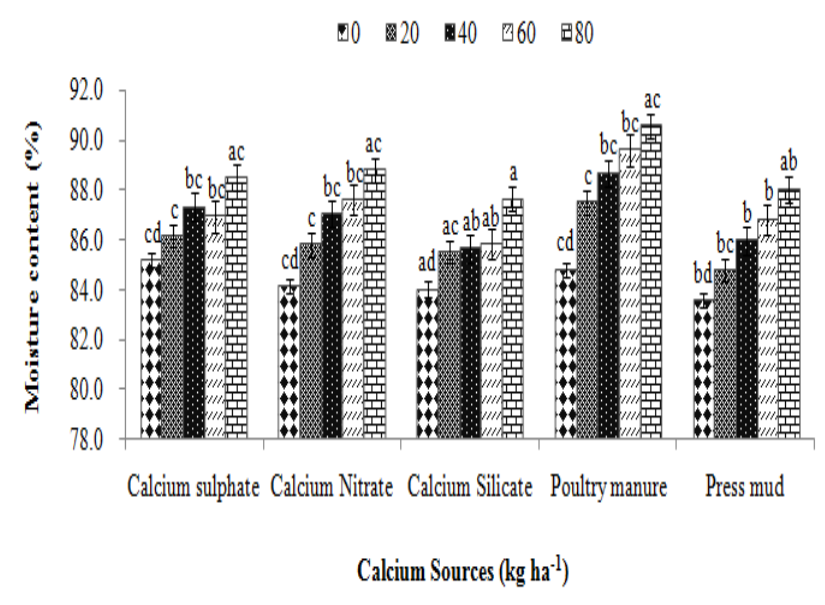

Fig. 2. Changes in moisture content of hybrid tomato as influenced by various sources and levels of calcium

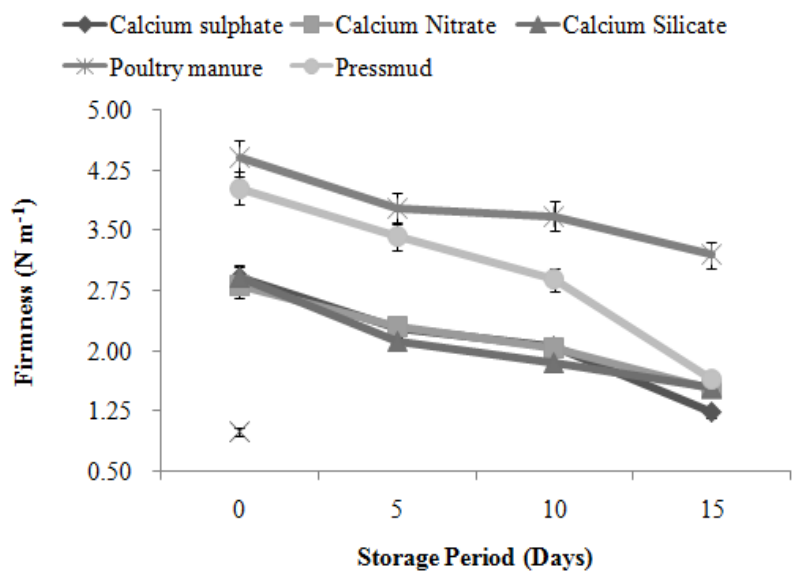

Fig. 4. Changes in fruit firmness of hybrid tomato as influenced by various sources and levels of calcium during storage period of 15 days

Table 2. Changes in fruit moisture content of hybrid tomato as influenced by various sources and levels of calcium during storage period of 15 days

\begin{tabular}{llllll}
\hline \multicolumn{1}{c}{ Calcium sources } & \multicolumn{5}{c}{ Fruit moisture content (\%) } \\
\cline { 2 - 6 } & \multicolumn{5}{c}{ Storage period (Days) } \\
\cline { 2 - 6 } & Initial & $\mathbf{5}$ & $\mathbf{1 0}$ & $\mathbf{1 5}$ & Mean \\
\hline Calcium sulphate & $90.5^{\mathrm{a}}$ & $87.3^{\mathrm{ac}}$ & $84.7^{\mathrm{ac}}$ & $82.9^{\mathrm{ab}}$ & 86.3 \\
Calcium nitrate & $91.7^{\mathrm{bd}}$ & $88.5^{\mathrm{bc}}$ & $86.0^{\mathrm{bc}}$ & $84.1^{\mathrm{b}}$ & 87.6 \\
Calcium silicate & $92.8^{\mathrm{bd}}$ & $89.6^{\mathrm{bc}}$ & $87.1^{\mathrm{ac}}$ & $85.2^{\mathrm{b}}$ & 88.7 \\
Poultry manure & $94.9^{\mathrm{ad}}$ & $91.7^{\mathrm{ac}}$ & $89.1^{\mathrm{bc}}$ & $87.3^{\mathrm{ab}}$ & 90.7 \\
Pressmud & $93.7^{\mathrm{bd}}$ & $90.4^{\mathrm{bc}}$ & $87.6^{\mathrm{bc}}$ & $85.9^{\mathrm{b}}$ & 89.4 \\
Mean & 92.7 & 89.5 & 86.9 & 85.1 & 88.5 \\
& $\mathrm{~S}$ & & $\mathrm{~T}$ & $\mathrm{ST}$ \\
SEd & 0.32 & & 0.26 & 0.64 \\
CD $(\mathrm{P}=0.05)$ & 0.63 & & 0.51 & 1.26 \\
\hline
\end{tabular}

Mean of three replicates; SEd- Standard error of difference; CD-Critical difference

The higher fruit firmness $\left(6.85 \mathrm{~N} \mathrm{~m}^{-1}\right)$ was recorded in tomatoes harvested from poultry manure applied at 80 $\mathrm{kg} \mathrm{Ca} \mathrm{ha}^{-1}$ and the lowest firmness was recorded in no calcium applied control plot. It was reported that there was a gradual decline in the firmness of tomato fruits on ripening which undergoes compositional and structural modifications due to polyuronides and de-polymerization of pectin, increased enzyme activity, solubilization and degradation of cell wall polymers, tissue strength and intercellular adhesion during 
Table 3. Change in the fruit juice $\mathrm{pH}$ of hybrid tomato as influenced by various sources and levels of calcium.

\begin{tabular}{|c|c|c|c|c|c|c|}
\hline \multirow{3}{*}{ Calcium sources } & \multicolumn{5}{|c|}{ Tomato fruit juice $\mathrm{pH}$} & \multirow[b]{3}{*}{ Mean } \\
\hline & \multicolumn{5}{|c|}{ Levels of calcium $\left(\mathrm{kg} \mathrm{ha}^{-1}\right)$} & \\
\hline & 0 & 20 & 40 & 60 & 80 & \\
\hline Calcium sulphate & $4.08^{\mathrm{cd}}$ & $4.35^{c}$ & $4.33^{\mathrm{C}}$ & $4.20^{\mathrm{bc}}$ & $4.19^{\mathrm{ac}}$ & 4.23 \\
\hline Calcium nitrate & $4.13^{\mathrm{bd}}$ & $4.31^{b} \mathrm{c}$ & $4.21^{\mathrm{b}}$ & $4.08^{\mathrm{b}}$ & $4.07^{\mathrm{ab}}$ & 4.16 \\
\hline Calcium silicate & $3.85^{\mathrm{cd}}$ & $4.18^{\mathrm{C}}$ & $4.08^{b c}$ & $3.95^{\mathrm{ac}}$ & $3.94^{\mathrm{ac}}$ & 4.00 \\
\hline Poultry manure & $3.73^{\mathrm{ad}}$ & $3.63^{\mathrm{a}} \mathrm{C}$ & $3.46^{\mathrm{ab}}$ & $3.34^{\mathrm{ab}}$ & $3.26^{\mathrm{ab}}$ & 3.48 \\
\hline Pressmud & $3.84^{\mathrm{bd}}$ & $3.74^{\mathrm{b}} \mathrm{c}$ & $3.61^{\mathrm{b}}$ & $3.60^{\mathrm{ab}}$ & $3.67^{\mathrm{a}}$ & 3.69 \\
\hline Mean & $\begin{array}{l}3.93 \\
S \\
0.01\end{array}$ & 4.04 & $\begin{array}{l}3.94 \\
L \\
0.01\end{array}$ & 3.83 & $\begin{array}{l}3.82 \\
\text { SL } \\
0.03\end{array}$ & 3.91 \\
\hline$C D(P=0.05)$ & 0.03 & & 0.03 & & 0.06 & \\
\hline
\end{tabular}

Mean of three replicates; SEd- Standard error of difference; CD-Critical difference

Table 4. Changes in fruit juice $\mathrm{pH}$ of hybrid tomato as influenced by various sources and levels of calcium during the storage period of 15 days

\begin{tabular}{lllllc}
\hline & \multicolumn{5}{c}{ Tomato fruit juice pH } \\
\hline \multirow{2}{*}{ Calcium sources } & \multicolumn{5}{c}{ Storage period (Days) } \\
\cline { 2 - 6 } & Initial & 5 & 10 & 15 & Mean \\
\hline Calcium sulphate & $4.04^{\mathrm{ac}}$ & $4.08^{\mathrm{ad}}$ & $4.18^{\mathrm{ab}}$ & $4.61^{\mathrm{a}}$ & 4.23 \\
Calcium nitrate & $3.97^{\mathrm{abc}}$ & $4.01^{\mathrm{abd}}$ & $4.11^{\mathrm{ab}}$ & $4.54^{\mathrm{ab}}$ & 4.16 \\
Calcium silicate & $3.81^{\mathrm{ac}}$ & $3.86^{\mathrm{ab}}$ & $3.95^{\mathrm{ab}}$ & $4.38^{\mathrm{a}}$ & 4.00 \\
Poultry manure & $3.29^{\mathrm{bc}}$ & $3.34^{\mathrm{bcd}}$ & $3.44^{\mathrm{bc}}$ & $3.86^{\mathrm{abc}}$ & 3.48 \\
Pressmud & $3.50^{\mathrm{abc}}$ & $3.55^{\mathrm{abd}}$ & $3.65^{\mathrm{ab}}$ & $4.07^{\mathrm{ab}}$ & 3.69 \\
Mean & 3.72 & 3.77 & 3.87 & 4.29 & 3.91 \\
SEd & $\mathrm{S}$ & & $\mathrm{L}$ & $\mathrm{SXL}$ \\
CD (P=0.05) & 0.01 & & 0.01 & 0.03 & 0.03 \\
\hline
\end{tabular}

Mean of three replicates; SEd- Standard error of difference; CD-Critical difference

ripening (Tilahun et al., 2017; Fan et al., 2017). The fruit firmness increases with increasing concentration of calcium, as it retards ethylene production, respiration rates; it also maintains cell turgor pressure and membrane integrity by binding to proteins and phospholipids, which stabilizes plasma membrane and improves fruit firmness (Azad et al., 2019; Haleema et al., 2020).

\section{Fruit juice $\mathbf{p H}$}

The analytical data on fruit juice $\mathrm{pH}$ values differed significantly with various calcium sources and their levels of application on storage period (Table 3 and 4). The $\mathrm{pH}$ value ranges from 3.48 to 4.23 .Lesser $\mathrm{pH}$ was recorded in tomatoes harvested with poultry manure applied at $80 \mathrm{~kg} \mathrm{Ca} \mathrm{ha}^{-1}$ (3.26). It is known that the $\mathrm{pH}$ of the tomato fruit juice increases on ripening due to a decrease in the hydrogen ions concentration attributed to the organic acid's conversion into sugars (BarragánIglesias et al., 2018; Demes et al.,2021). A decline in acidity was attributed to the increased activity of citric acid glyoxylate during ripening (Rathore et al., 2007; Demes et al., 2021). However, the inverse relationship between $\mathrm{pH}$ and titratable acidityon ripening was following the results reported by Moneruzzaman et al. (2008). The lowest fruit juice $\mathrm{pH}$ was maintained by calcium, which agreed with the study conducted by Demes et al.(2021), who experimented with the effect of calcium on tomato fruit quality.

\section{Titratable acidity (TA)}

The results showed significant differences in the titratable acidity with the application of various calcium sources and levels and the acidity varies from 0.38 to $0.42 \%$ (Fig. 5 and Table 5). The highest acidity $(0.47 \%)$ was recorded in fruits harvested from plots applied with poultry manure at $80 \mathrm{~kg} \mathrm{Ca} \mathrm{ha}^{-1}$ and the lowest acidity $(0.38 \%)$ was found at calcium sulphate at $20 \mathrm{~kg} \mathrm{CA} \mathrm{ha}^{-1}$. On ripening, the TA decreased, perhaps on increasing calcium concentration; the acid content got retained, increasing the acidity. The decline in acidity on ripening irrespective of different calcium sources might be due to the uptake of organic acids as a respiration substrate, acid to sugar conversion, metabolic translocation and transformation during storage 


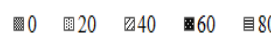

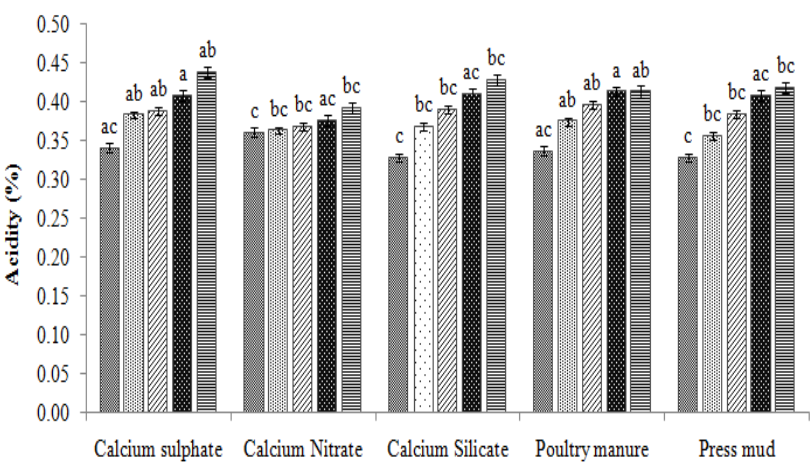

Calcium Sources $\left(\mathrm{kg} \mathrm{ha}^{-1}\right)$

Fig. 5. Changes in the acidity of hybrid tomato as influenced by various sources and levels of calcium
目0 $20 \quad 040 \quad-660 \square 80$

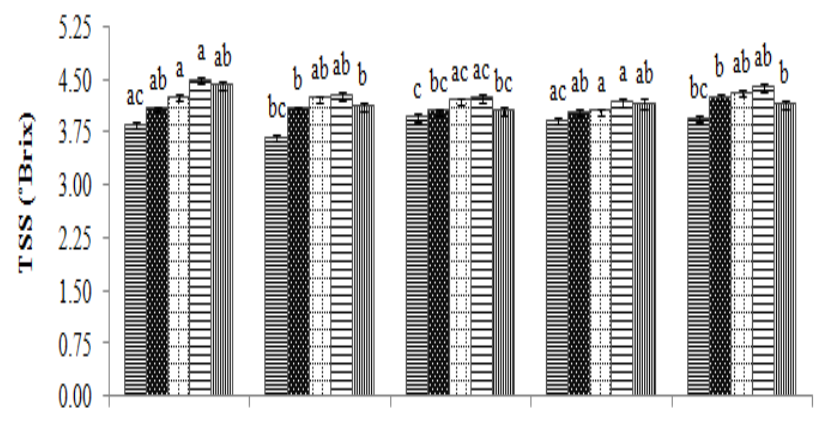

Calcium sulphate Calcium Nitrate Calcium Silicate Poultrymanure Press mud

Calcium Sources $\left(\mathrm{kg} \mathrm{ha}^{-1}\right)$

Fig. 6. Changes in total soluble solids of hybrid tomato as influenced by various sources and levels of calcium

Table 5. Changes in titratable acidity of the fruits of hybrid tomato as influenced by various sources and levels of calcium during storage period of 15 days.

\begin{tabular}{llllll}
\hline & \multicolumn{5}{c}{ Titrable acidity (\%) } \\
\hline \multirow{2}{*}{ Calcium sources } & \multicolumn{5}{c}{ Storage period (Days) } \\
\cline { 2 - 6 } & Initial & $\mathbf{5}$ & $\mathbf{1 0}$ & $\mathbf{1 5}$ & Mean \\
\hline Calcium sulphate & $0.43^{\mathrm{a}}$ & $0.40^{\mathrm{a}}$ & $0.36^{\mathrm{a}}$ & $0.34^{\mathrm{a}}$ & 0.38 \\
Calcium nitrate & $0.43^{\mathrm{bc}}$ & $0.40^{\mathrm{abc}}$ & $0.37^{\mathrm{bc}}$ & $0.34^{\mathrm{bc}}$ & 0.39 \\
Calcium silicate & $0.45^{\mathrm{abc}}$ & $0.42^{\mathrm{a}}$ & $0.39^{\mathrm{abc}}$ & $0.36^{\mathrm{abc}}$ & 0.40 \\
Poultry manure & $0.47^{\mathrm{a}}$ & $0.43^{\mathrm{c}}$ & $0.40^{\mathrm{a}}$ & $0.38^{\mathrm{a}}$ & 0.42 \\
Pressmud & $0.45^{\mathrm{c}}$ & $0.42^{\mathrm{ab}}$ & $0.39^{\mathrm{c}}$ & $0.36^{\mathrm{c}}$ & 0.41 \\
Mean & 0.44 & 0.41 & 0.38 & 0.36 & 0.40 \\
SEd & $\mathrm{S}$ & & $\mathrm{T}$ & $\mathrm{ST}$ & 0.0131 \\
$\mathrm{CD}(\mathrm{P}=0.05)$ & 0.0065 & & 0.01 & 0.0258 & \\
\hline
\end{tabular}

Mean of three replicates; SEd- Standard error of difference; CD-Critical difference

Table 6. Changes in the Total soluble solids in the fruits of hybrid tomato as influenced by various sources and levels of calcium during storage period of 15 days.

\begin{tabular}{|c|c|c|c|c|c|}
\hline \multirow{3}{*}{ Calcium sources } & \multicolumn{5}{|c|}{ Total soluble solids ( ${ }^{\circ}$ Brix) } \\
\hline & \multicolumn{5}{|c|}{ Storage period (Days) } \\
\hline & Initial & 5 & 10 & 15 & Mean \\
\hline Calcium sulphate & $3.50^{a}$ & $3.93^{\mathrm{a}} \mathrm{C}$ & $4.25^{\mathrm{ac}}$ & $4.46^{\mathrm{ab}}$ & 4.04 \\
\hline Calcium nitrate & $3.56^{\text {bd }}$ & $3.99^{b c}$ & $4.31^{\mathrm{bc}}$ & $4.52^{b}$ & 4.09 \\
\hline Calcium silicate & $3.62^{\text {bd }}$ & $3.99^{b c}$ & $4.34^{\mathrm{ac}}$ & $4.51^{\mathrm{ab}}$ & 4.12 \\
\hline Poultry manure & $3.84^{\mathrm{ad}}$ & $4.27^{\mathrm{ac}}$ & $4.59^{\mathrm{bc}}$ & $4.80^{\mathrm{b}}$ & 4.38 \\
\hline Pressmud & $3.66^{\text {bd }}$ & $4.08^{\mathrm{bc}}$ & $4.41 \mathrm{bc}$ & $4.61^{b}$ & 4.19 \\
\hline \multirow[t]{2}{*}{ Mean } & 3.64 & 4.05 & 4.38 & 4.58 & 4.16 \\
\hline & S & & $\mathrm{T}$ & & ST \\
\hline SEd & 0.03 & & 0.03 & & 0.07 \\
\hline$C D(P=0.05)$ & 0.07 & & 0.05 & & 0.13 \\
\hline
\end{tabular}

Mean of three replicates; SEd- Standard error of difference; CD-Critical difference

(Usenik et al., 2013, Azad et al., 2019). The acidity was increased with increasing calcium levels, which ispossibly due to the inhibitory effect of calcium on ripening and reduction in metabolic activity, as reported earlier (Oz and Ulukanli, 2014; Demes et al., 2021).

\section{Total soluble solids (TSS)}

The data onfruit TSS showed a significant impact of various sources and levels of calcium on the storage period and the values ranged from 4.04 to $4.38{ }^{\circ}$ Brix (Fig. 6 and Table 6). The lowest TSS (4.04 ${ }^{\circ}$ Brix) was 
recorded in the tomato harvested from plot applied with poultry manure as $80 \mathrm{~kg} \mathrm{Ca} \mathrm{ha-1}$ and the highest TSS $\left(4.74^{\circ}\right.$ Brix) was recorded in calcium sulphate treated plot at $20 \mathrm{~kg} \mathrm{Ca} \mathrm{ha}^{-1}$ and control plot (NPK control). The TSS of tomato fruits normally increases on ripening, possibly attributed to the accumulation of sugars, starch-sugar conversion and cell wall polysaccharide hydrolysis (Youssef et al. 2012). There was a gradual increase in TSS on maturation, which might be due to the accumulation of simple sugars upon ripening (Kauret al., 2006, Azad et al., 2019). The mean total soluble solids decreased with increased calcium concentrationand ascribed to the reduced metabolic activity and slow conversion of carbohydrates to sugars (Aghdam et al., 2012; Demes et al., 2021).

\section{Conclusion}

The present study concluded that the application of different calcium sources at various levels greatly influenced the fruit quality of hybrid tomato and the shelf life. The quality attributes such as $\mathrm{pH}$, total soluble solids, titratable acidity, firmness, moisture content and physiological weight loss were positively influenced by poultry manure applied at $80 \mathrm{~kg} \mathrm{Ca} \mathrm{ha}^{-1}$. On comparing all the sources and levels of calcium, the application of poultry manure at $80 \mathrm{~kg} \mathrm{Ca} \mathrm{ha}^{-1}$ was found very effective in improving hybrid tomato's quality parameters and shelf-life.

\section{ACKNOWLEDGEMENTS}

The authors wish to express their profound gratitude to the Department of Soil Science and Agricultural Chemistry, Tamil Nadu Agricultural University, Coimbatore for providing the necessary facilities to carry out the experiment.

\section{Conflict of interest}

The authors declare that they have no conflict of interest.

\section{REFERENCES}

1. Aghdam, M. S., Hassanpouraghdam, M. B., Paliyath, G. \&Farmani, B. (2012). The language of calcium in postharvest life of fruits, vegetables and flowers. Scientia Horticulturae, 144,102-115. https://doi.org/10.1016/j.scienta.201 2.07.007

2. Al-Qurashi, A. D. \& Awad, M. A. (2019). Postharvest gibberellic acid, 6-benzylaminopurine and calcium chloride dipping affect quality, antioxidant compounds, radical scavenging capacity and enzymes activities of 'Grand Nain' bananas during shelf life. Scientia Horticulturae, 253, 187-194. https://doi.org/10.1016/j.scienta.20 19.04 .044

3. AOAC (2000). Official Methods of Analysis. 17th Edition,
The Association of Official Analytical Chemists, Gaithersburg, MD, USA.

4. Azad, M. A. K., Islam, M. S., Hossen, M. I. \& Eaton, T. E. J. (2019). Yield and fruit quality of tomato as influenced by calcium and mulching in rooftop cultivation. Agricultural Sciences, 10(07), 893.

5. Barragán-Iglesias, J., Méndez-Lagunas, L. L., \& Rodríguez-Ramírez, J. (2018). Ripeness indexes and physicochemical changes of papaya (Carica papaya L. cv. Maradol) during ripening on-tree. Scientia Horticulturae, 236, 272-278. https://doi.org/10.1016/j.scienta.201 7.12.012

6. Chew, E. Y., Clemons, T. E., San Giovanni, J. P., Danis, R. P., Ferris, F. L., Elman, M. J. \& Age-Related Eye Disease Study 2 (AREDS2) Research Group. (2014). Secondary analyses of the effects of lutein/zeaxanthin on agerelated macular degeneration progression: AREDS2 report No. 3. JAMA Ophthalmology, 132(2), 142-149. doi:10.1001/jamaophthalmol.2013.7376.

7. Demes, R., Satheesh, N. \& Fanta, S. W. (2021). Effect of different concentrations of the gibberellic acid and calcium chloride dipping on quality and shelf-life of Kochorovariety tomato. Philippine Journal of Science, 150(1), 335-349.

8. Dorais, M., Ehret, D. L. \& Papadopoulos, A. P. (2008). Tomato (Solanum lycopersicum) health components: from the seed to the consumer. Phytochemistry Reviews, 7 (2),231. https://doi.org/10.1007/s11101-007-9085-x

9. Fan, X., Zhao, H., Wang, X., Cao, J. \& Jiang, W. (2017). Sugar and organic acid composition of apricot and their contribution to sensory quality and consumer satisfaction. Scientia Horticulturae, 225, 553-560. https:// doi.org/10.1016/j.scienta.2017.07.016

10. Fouda, K. F. (2017). Effect of interaction among $N$ forms and calcium sources on quality and chemical composition of tomato (Lycopersicon esculentum). Egyptian Journal of Soil Science, 57(1), 61-71.

11. Frenkel, C. \& Hartman, T. G. (2012). Decrease in fruit moisture content heralds and might launch the onset of ripening processes. Journal of Food Science, 77(10),S365 -S376. https://doi.org/10.1111/j.17503841.2012.02910.x

12. Gaikwad, P. S., Yadav, B. K. \& Sugumar, A. (2021). Fabrication of natural colorimetric indicators for monitoring freshness of ready-to-cook idli batter. Packaging Technology and Science, 34(4), 211-218. https://doi.org/10.1002/ pts. 2550

13. Gao, Q., Xiong, T., Li, X., Chen, W., \& Zhu, X. (2019). Calcium and calcium sensors in fruit development and ripening. Scientia Horticulturae, 253, 412-421. https:// doi.org/10.1016/j.scienta.2019.04.069

14. Guo, Q., Su, J., Xie, W., Tu, X., Yuan, F., Mao, L. \& Gao, Y. (2020). Curcumin-loaded pea protein isolate-high methoxyl pectin complexes induced by calcium ions: Characterization, stability and in vitro digestibility. Food Hydrocolloids, 98, 105284. https://doi.org/10.1016/j.foodhyd.2019.1 05284

15. Haleema, B., Rab, A., Hussain, S. A., Sajid, M., Arif, M., Shah, S. T. \& Basit, A. (2020). Influence of calcium concentrations and sources on the fruit quality of tomato (Lycopersicon esculentum mill) at different storage conditions. Fresenius environmental bulletin, 29(3), 1866-1877.

16. Kaur, D., Sharma, R., Abas Wani, A., Singh Gill, B. \& Sogi, D. S. (2006). Physicochemical changes in seven 
tomato (Lycopersicon esculentum) cultivars during ripening. International Journal of Food Properties, 9(4), 747757. https://doi.org/10.1080/10942910600575716

17. Lobos, T. E., Retamales, J. B. \& Hanson, E. J. (2021). Early preharvest calcium sprays improve postharvest fruit quality in 'Liberty' high bush blueberries. Scientia Horticulturae, 277,109790.https://doi.org/10.1016/j.scienta.202 0.109790

18. Madani, B., Mohamed, M. T. M., Watkins, C. B., Kadir, J., Awang, Y. \& Shojaei, T. R. (2014). Preharvest calcium chloride sprays affect ripening of Eksotikall' papaya fruits during cold storage. Scientia Horticulturae, 171, 6-13. https://doi.org/10.1016/j.scienta.2014.03.032

19. Moneruzzaman, K. M. Hossain, A. B. M. S., Sani, W. \& Saifuddin, M. (2008). Effect of stages of maturity and ripening conditions on the biochemical characteristics of tomato. American Journal of Biochemistry and Biotechnology, 4(4), 336-344.

20. Oz, A. T. \& Ulukanli, Z. (2014). The Effects of Calcium Chloride and 1 $\square$ Methylcyclopropene (1-MCP) on the Shelf Life of Mulberries (Morus alba L.). Journal of Food Processing and Preservation, 38(3), 1279-1288. https:// doi.org/10.1111/jfpp.12089

21. Ranganna, S. (2000). Handbook of Analysis and Quality Control for Fruits and Vegetable Products Tata McGraw Hill Publishing Co. Ltd., New Delhi.

22. Rathore, H. A., Masud, T., Sammi, S. \& Soomro, A. H. (2007). Effect of storage on physico-chemical composition and sensory properties of mango (Mangifera indica L.) variety Dosehari. Pakistan Journal of Nutrition, 6(2), 143148.

23. Sajid, M., Ullah, I., Rab, A., Shah, S. T., Basit, A., Bibi, F. \& Ahmad, M. (2020). 2. Foliar application of calcium improves growth, yield and quality of tomato cultivars. Pure and Applied Biology (PAB), 9(1), 10-19. http:// dx.doi.org/10.19045/bspab.2020.90002

24. Sotiropoulos, Thomas, Antonios Voulgarakis, Dionisios Karaiskos, Theocharis Chatzistathis, Ioannis Manthos, Olga Dichala \& Areti Mpountla (2021). Foliar Calcium Fertilizers Impact on Several Fruit Quality Characteristics and Leaf and Fruit Nutritional Status of the 'Hayward' Kiwi fruit Cultivar." Agronomy 11,2:235. https://doi.org/10.3390/ agronomy 11020235

25. Soundharya, N., Srinivasan, S., Sivakumar, T. \& Kamalkumaran, P. (2019). Effect of foliar application of nutrients and silicon on yield and quality traits of tomato (Lycopersicon esculentum L.). International Journal of Pure Bioscience, 7, 526-531.http://dx.doi.org/10.18782/23 20-7051.7491

26. Tilahun, S., Seo, M. H. \& Jeong, C. S. (2017). Review on factors affecting the quality and antioxidant properties of tomatoes. African Journal of Biotechnology, 16(32), 16781687. https://doi.org/10.5897/AJB2017.16054

27. Usenik, V., Stampar, F. \& Kastelec, D. (2013). Phytochemicals in fruits of two Prunus domestica L. plum cultivars during ripening. Journal of the Science of Food and Agriculture, 93(3), 681-692. https://doi.org/10.1002/jsf a.5783

28. Wei, D. \& Zhao, X. H. (2020). Calcium maintained higher quality and enhanced resistance against chilling stress by regulating enzymes in reactive oxygen and biofilm metabolism of Chinese winter jujube fruit. Journal of Food Biochemistry, (4), e13161. https://doi.org/10.1111/jfbc.13161

29. Yang, Y., Wang, Q., Chen, Q., Yin, X., Qian, M., Sun, X. \& Yang, Y. (2017). Genome-wide survey indicates diverse physiological roles of the barley (Hordeum vulgare L.) calcium-dependent protein kinase genes. Scientific reports, 7(1), 1-15. https://doi.org/10.1038/s41598-01705646-w

30. Youssef, K., Ligorio, A., Sanzani, S. M., Nigro, F. \& Ippolito, A. (2012). Control of storage diseases of citrus by pre-and postharvest application of salts. Postharvest Biology and Technology, 72,57-63. https://doi.org/10.1016/ j.postharvbio.2012.05.004

31. Zhao, Y. \& Wang, C. (2015). Effect of calcium chloride in combination with salicylic acid on post-harvest freshness of apples. Food Science and Biotechnology, 24(3),11391146.https://doi.org/10.1007/s10068-015-0145-5 